Journal of Molecular Genetics 2 (1): 15-19, 2010

ISSN: $2070-4267$

(C) Medwell Journals, 2010

\title{
Genetic Polymorphism Study of Promoter Region of Interleukin-2 Gene and its Association with Certain Milk Associated Traits in Indian Crossbred Cattle
}

\author{
${ }^{1}$ Ved Prakash, ${ }^{2}$ Tarun K. Bhattacharya and ${ }^{3}$ O.P. Pandey \\ ${ }^{1}$ Central Sheep and Wool Research Institute, Avikanagar, P.O. Box 304501, Rajasthan, India \\ ${ }^{2}$ Rajendranagar, Hyderabad, P.O. Box 500038, Andhra Pradesh, India \\ ${ }^{3}$ Animal Genetics Division, Indian Veterinary Research Institute, Izatnagar, Bareilly, \\ P.O. Box 243122, Uttar Pradesh, India
}

\begin{abstract}
A study was conducted to explore polymorphism at the promoter region of interleukin-2 gene in Indian Sahiwal X Holstein Friesian crossbred cattle and its effect on certain milk associated traits. Single strand conformation polymorphism study revealed presence of three genotypes ( $\mathrm{AA}, \mathrm{AB}$ and $\mathrm{AC}$ ) and three alleles $(\mathrm{A}, \mathrm{B}$ and $\mathrm{C}$ ) in the population. The frequencies of $\mathrm{AA}, \mathrm{AB}$ and $\mathrm{AC}$ genotypes were estimated as $0.35,0.47$ and 0.18 , respectively whereas the frequencies of $\mathrm{A}, \mathrm{B}$ and $\mathrm{C}$ alleles were found as $0.68,0.22$ and 0.10 , respectively.
\end{abstract}

Key words: Interleukin-2, crossbred cattle, promoter, polymorphism, association, somatic cell

\section{INTRODUCTION}

Interleukin-2 plays the central molecule for the activation of both helper and cytotoxic T-cells leading to clonal expansion of these cells. It supports the proliferation of activated $\mathrm{T}$ and $\mathrm{B}$ lymphocytes, contributes to generation of lymphokine activated killer cells and influences the oxidative burst by monocytes/macrophages. Interleukin-2 (IL-2) or T-Cell Growth Factor (TCGF) is an inducible antigen-nonspecific lymphokine synthesized and secreted by a subset of mature lymphocytes after stimulation by antigen, mitogen, or alloantigen (Morgan et al., 1976). Several secondary signals are required for maximal expression of IL-2. Later studies have shown that production of $\mathrm{IL}-2$ is not a exclusive property of activated T-cells, some murine B-cell lines and splenic B-cells activated with calcium ionophores PMA (Taira et al., 1987) or with Staphylococcus aureus (Walker et al., 1988) may also produce IL-2. Transformed T-cells and B-cells, Leukemia cells, LAK cells (lymphokine-activated killer cells) and NK-cells also secrete IL-2. With increasing age the antigen and mitogen-stimulated synthesis of $\mathrm{IL}-2$ decreases and hence, also T-cell mediated immune responses decrease. IL-2 has significant association with several diseases like mastitis in cattle (Alluwaimi et al., 2003), Leishmeniasis and T. cruzi infection in cattle (Diez et al., 1991), trypanosomosis in cattle, humans and mice (Mansfield, 1989; De Baetselier, 1996; Taylor, 1998), HIV (Alharthi et al., 1998; Kinter et al., 1995) etc. Bhattacharya et al. (2002) performed polymorphism study of interleukin-2 (IL-2) gene in cattle (both taurine and indicine) and water buffalo applying PCR-RSP technique. Luhken et al. (2000) detected single strand conformation polymorphism in ovine IL-2 gene. Polymorphisms in cytokine genes might regulate cytokine production (Warle et al., 2003) as shown in human IL-2 for -330 promoter polymorphism (Hoffmann et al., 2001, Matesanz et al., 2004).

Launching of extensive cross breeding programmes in tropics has resulted in improvement of the quality of livestock but susceptibility of these livestock to various diseases including exotic diseases has increased. Residues due to pesticides, chemicals, antibiotics and heavy metals in livestock and livestock products are critical both for human and livestock health and have become a new concern in the post World Trade Organization (WTO) regime. Thus, it becomes necessary to identify genes that influence both general and specific immunocompetence. Once correlation between cytokines genotype and animal health and production are identified these markers can be incorporated into breeding selection criteria. Hence, the objective of the present study was to explore polymorphism at the promoter region of IL-2 gene and its effect on certain milk associated traits in Indian Crossbred cattle.

Corresponding Author: Ved Prakash, Central Sheep and Wool Research Institute, Avikanagar, P.O. Box 304501, Rajasthan, India 


\section{MATERIALS AND METHODS}

Experimental animals and sample preparation: A total of 250 Indian Sahiwal x Holstein Friesian hybrid cattle maintained at Instructional Dairy Farm, G.B. Pant University of Agriculture and Technology, Pantnagar, Uttaranchal, India were included for the present investigation. About $5 \mathrm{~mL}$ of blood was collected from each animal and genomic DNA was isolated from blood following standard protocol of Sambrook and Russel (2001).

PCR amplification: A $209 \mathrm{bp}$ promoter region of Interleukin-2 gene was analyzed for detection of polymorphism for which the primers were designed on the basis of bovine sequence (Acc. No. M12791) with the help of DNASTAR software (Lasergene Inc., USA). The sequence of the primers was forward: 5'-AAG AGT CAT CAG AAG AGG AA-3 and reverse: 5'-TTG TAC ATT GTG GCA GGA GTT G-3'.

For amplification of the fragment, optimum PCR reaction was performed in a total volume of $25 \mu \mathrm{L}$ with $80 \mathrm{ng}$ of genomic DNA, $40 \mathrm{ng}$ of each primer, $1.5 \mathrm{mM}$ of $\mathrm{MgCl}_{2}, 200 \mu \mathrm{M}$ of each dNTP, $1 \times \mathrm{PCR}$ reaction buffer and $1 \mathrm{U}$ of Taq DNA polymerase (MBI Fermentas). DNA was initially denatured for $2 \mathrm{~min}$ at $95^{\circ} \mathrm{C}$, then 30 cycles of denaturation for $30 \mathrm{sec}$ at $95^{\circ} \mathrm{C}$, annealing for $45 \mathrm{sec}$. at $59^{\circ} \mathrm{C}$ and extension for $30 \mathrm{sec}$ at $72^{\circ} \mathrm{C}$ followed by final extension for $5 \mathrm{~min}$ at $72^{\circ} \mathrm{C}$.

Single Strand Conformation Polymorphism (SSCP): A $12 \%$ native PAGE (50:1, Acrylamide and Bis-acrylamide) with $5 \%$ glycerol was prepared. A total volume of $3 \mu$ : of PCR product was mixed with $15 \mu \mathrm{L}$ formamide dye $(95 \%$ Formamide, 0.025\% Xylene cyanol, $0.025 \%$ Bromophenol blue, $0.5 \mathrm{M}$ EDTA). The product was denatured at $95^{\circ} \mathrm{C}$ for $5 \mathrm{~min}$ and snapped chill on ice for $15 \mathrm{~min}$. Finally, mixture was loaded in the gel and electrophoresis was performed at $4^{\circ} \mathrm{C}$ temperature for $12 \mathrm{~h}$ at $200 \mathrm{~V}$. After electrophoresis, silver nitrate staining was performed to visualize banding patterns (Vohra et al., 2006).

Purification of PCR product: The PCR products of different genotypes were run on $0.8 \%$ agarose gel. The product was visualized under UV-vis trans-illuminator and the region of gel having DNA fragment of interest were cut and the DNA was isolated from that part of gel using MinElute gel extraction Kit (Qiagen, Germany).

Cloning: The purified PCR products were cloned in the pDRIVE cloning Vector and it was transformed into $E$. coli
DH5 $\alpha$ strain. The recombinant clones were identified by white colour on X-gal-IPTG plates. In order to minimize the number of clones to be handled, clones were initially checked by the colony PCR and later confirmed by plasmid-PCR. The positive samples were reconfirmed by restriction enzyme digestion of the plasmid DNA with EcoR1.

Sequencing: Sequencing of two recombinant clones were performed in both directions by ABI prism 377 DNA sequencer (Perkin-Elmer) using Sanger's dideoxy chain termination method. The T $7 \mathrm{~F}$ and SP6R primers were used for the sequencing of the clones from sides of the insert.

Statistical analysis: Gene and genotype frequencies were calculated by gene counting method described by Falconar and Mackay (1998). Sequence analysis was performed with DNASTAR Software (Lasergene Inc., USA). For megablast, the Jukes-Cantor method was used to calculate the distances in terms of similarity of sequences. For preparation of tree, Kimura method was used. The traits considered for the present study were Somatic Cell Score ( SCS), Total Milk production ( TMY), Lactation Length (LL), Daily Milk production (DMY) and Peak Yield during first lactation (PY). Milk somatic cell score was calculated from somatic cell count by logarithmic transformation. For exploring the effect of polymorphism on those traits, least squares-maximum likelihood method (Harvey, 1991) was employed with genotype and Age at First Calving (AFC) as fixed effectsand sire as random effect. The age at first calving was grouped into three classes namely class I (age at first calving as 800-1200 days), class II (age at first calving as 1201-1600 days) and class III (age at first calving as 1601-2200 days).

\section{RESULTS AND DISCUSSION}

Genotypes: Three genotypes namely $\mathrm{AA}, \mathrm{AB}$ and $\mathrm{AC}$ were found in the crossbred population. At this locus, there were presence of three alleles namely $\mathrm{A}, \mathrm{B}$ and $\mathrm{C}$. Both homozygous and heterozygous animals were found in the population. The results depict that this locus is polymorphic implicating its due importance in the characterization, evolutionary and gene-trait relationship study.

Frequencies: The frequencies of $\mathrm{AA}, \mathrm{AB}$ and $\mathrm{AC}$ genotypes were estimated as $0.35,0.47$ and 0.18 in the crossbred population while allelic frequencies were found 
as $0.68,0.22$ and 0.10 for $\mathrm{A}, \mathrm{B}$ and $\mathrm{C}$ alleles, respectively. In this population, $\mathrm{A}$ allele was having highest frequency whereas $\mathrm{C}$ allele was found to be at the lowest frequency. Bhattacharya et al. (2002) performed polymorphism study of IL-2 gene in Indigenous cattle and water buffalo revealing the presence of two alleles with A allele as predominant in both species. John et al. (1998) detected two novel single nucleotide polymorphisms in the IL-2 gene at positions-330 and +166 relative to the transcription start site in human. The +166 mutation occurs within the leader peptide and does not affect amino acid sequence. Luhken et al. (2000) detected a silent $\mathrm{A} / \mathrm{G}$ substitution at position 117 of exon 1 in ovine IL-2 gene. The crossbred population has developed from Indian Sahiwal and exotic Holstein Friesian and the 50\% exotic germplasm was maintained in the herd because $50 \%$ exotic blood level was found to be more suitable in Indian subcontinent where there was huge climatic and environmental stress. Besides, humidity was also very high which has been the most stressful factor during summer season. However, the crossbred animals were the product of inter-se-mating for several generations. Due to admixture of both indicine and taurine blood, heterozygotic frequency has possibly been higher and in the farm we are selecting animals on the basis of their milk production. Biologically, promoter region is very much important as this region is actually control the transcription of gene. The existence of polymorphism at promoter can have great impact on transcription and more specifically the expression of the gene. Hence, the identification of polymorphism at this region has been the first step towards the way of functional genomics study.

Allelic sequence variability: The genetic intersection study revealed that out of 209 bp, first 201 bp was promoter and the remaining was partial exon 1. All the sequences have been submitted to the NCBI GenBank and the accession numbers have been obtained as DQ821928 for A allele, DQ821929 for B allele and DQ821930 for C allele. From the sequence analysis it was observed that $\mathrm{A}$ allele differ from $\mathrm{B}$ and $\mathrm{C}$ allele by having cytosine instead of adenine at 102 nd position of nucleotide sequence, $\mathrm{B}$ allele differ from $\mathrm{A}$ and $\mathrm{C}$ by having cytosine at 161 st position instead of thymine (Fig. 1). Similarly, allele C differed from A and B by having thymine instead of adenine at 76 th position and cytosine instead of thymine at 77 th position, adenine instead of cytosine at 200 th position and guanine instead of adenine at 209th position of the fragment.

Percentage similarity between alleles: Percentage similarity study revealed that similarity between allele A and B was $99 \%$ whereas similarity of allele A with allele C was $97.6 \%$ and similarity of allele $B$ with allele $C$ was found to be $97.6 \%$. Such variability observed among alleles mainly attributed to the point mutation occurred in formation of alleles.

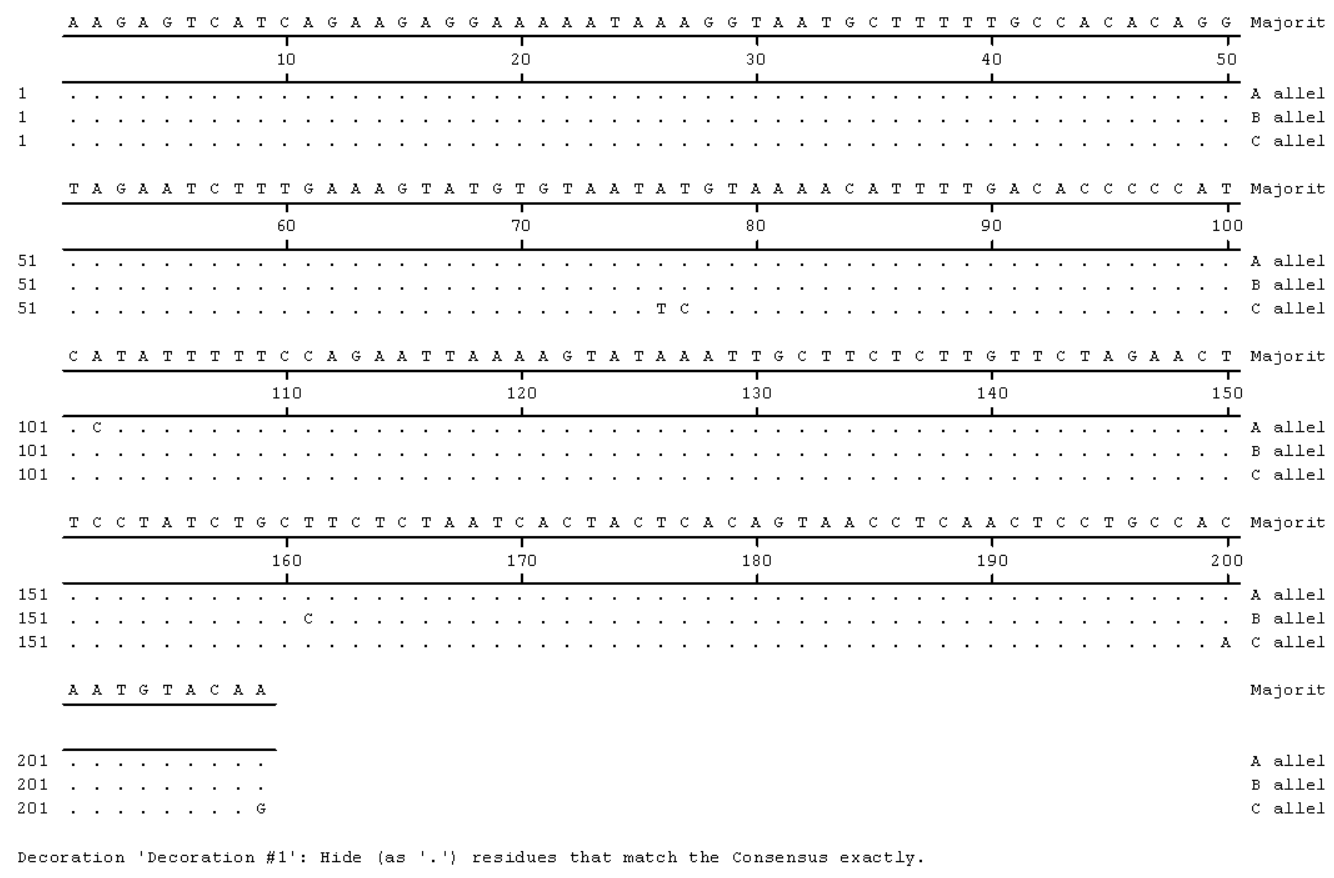

Fig. 1: Nucleotide alignment of different alleles of IL-2 promoter 
Table 1: Genotype-wise least square means of several traits in crossbred cattle

\begin{tabular}{llllll}
\hline Genotype & SCS & TMY (kg) & LL (Days) & DMY $\left.(\mathrm{kg} \mathrm{Day})^{-1}\right)$ & PY $(\mathrm{kg})$ \\
\hline AA & $1589.91 \pm 6.69$ & $2992 \pm 125^{*}$ & $343 \pm 10^{*}$ & $8.73 \pm 0.19^{*}$ & $16.7 \pm 0.4^{*}$ \\
AB & $1620.73 \pm 14.41$ & $3058 \pm 108^{*}$ & $343 \pm 09^{*}$ & $8.81 \pm 0.17^{*}$ & $16.7 \pm 0.4^{*}$ \\
AC & $1590.32 \pm 25.09$ & $3349 \pm 188^{* *}$ & $353 \pm 16^{* *}$ & $9.21 \pm 0.29^{* *}$ & $18.9 \pm 0.7^{* *}$ \\
\hline
\end{tabular}

Different asterisks indicate significant difference at $p<0.05$

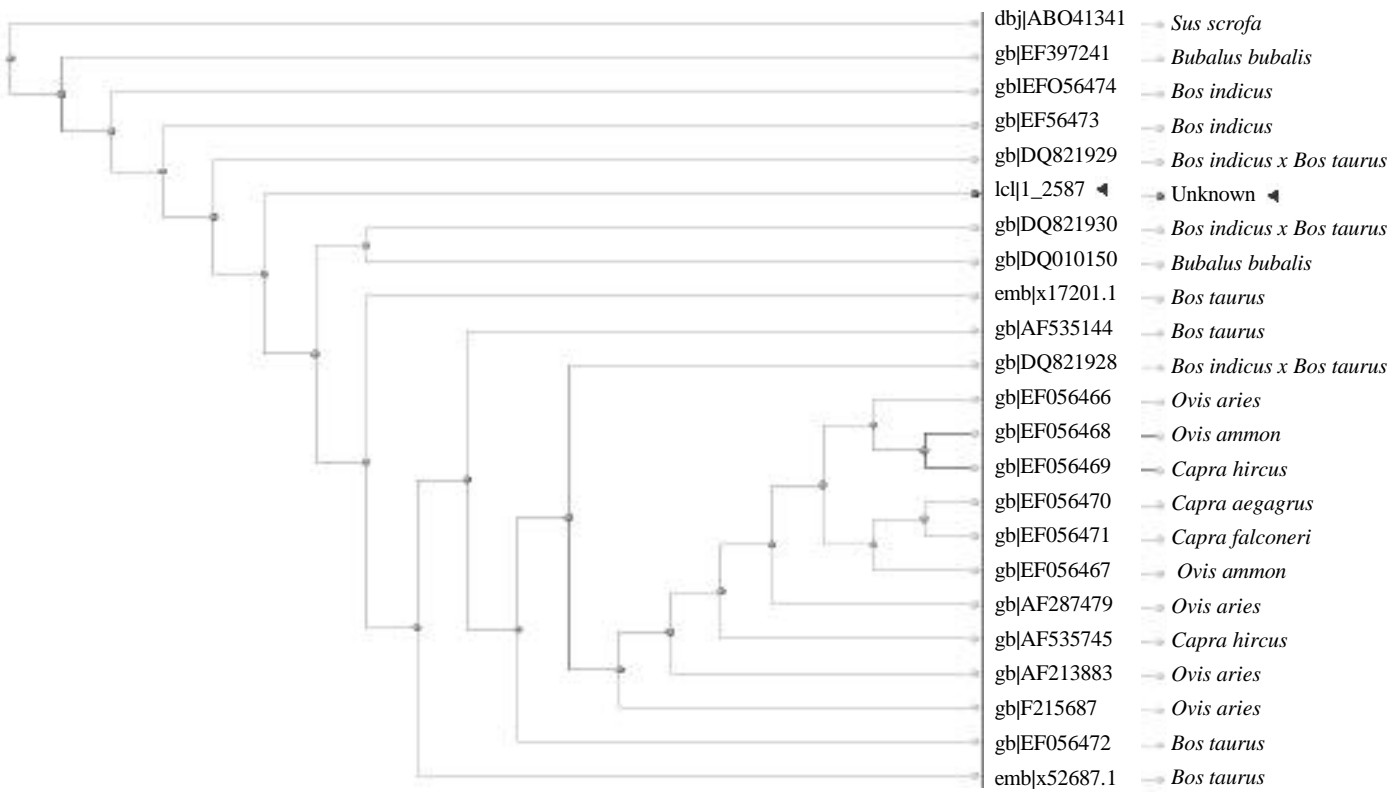

Fig. 2: Phylogenetic tree based on the sequence of the promoter region among various species. Here, the right most column shows the species name and the adjacent values are the corresponding accession number

Association study: The genotypes showed significant association with total milk yield, lactation length, daily milk yield and peak yield and non-significant association with somatic cell score during first lactation (Table 1). Genotype AC produced $12 \%$ more total milk yield than $\mathrm{AA}$ and $\mathrm{AB}$ genotype while the lactation length was $3 \%$ longer in $\mathrm{AC}$ genotype than $\mathrm{AA}$ genotype. In consequence, the daily milk yield was higher by $5.4 \%$ in AC genotype. Average peak yield was found to be $13 \%$ higher in $\mathrm{AC}$ than $\mathrm{AA}$ and $\mathrm{AB}$ genotype. Particularly, the presence of $\mathrm{C}$ allele showed higher yield than the $\mathrm{A}$ and $\mathrm{B}$ allele in the genotype. Thus, $\mathrm{C}$ allele may be favoured during selection of animals for milk production alongwith other selection criterion followed in the farm. With milk somatic cell score, promoter genotypes were not found to get associated significantly, although the magnitude was relatively higher in $\mathrm{AB}$ genotype than others. The lower score in $\mathrm{AC}$ genotype indicates relatively better milk hygiene. Overall, AC genotype showed best production performance as well as better udder health, supposed to be yielding hygienic clean milk.

Phylogenetic tree: On the basis of nucleotide sequences, the megablast software of NCBI was used to draw the phylogenetic tree (Fig. 2). Here, pig was the most distantly related species to the crossbred cattle whereas the taurus cattle and Bubalus bubalis buffalo were the most closely related species. But some of the taurine sequences showed their distant relationship with crossbred sequences. Caprine and ovine species was relatively distant from crossbred cattle. This kind of dendogram analysis suggests that the promoter sequence may be applied for evolutionary studies though there was very high conservation among species. As the species was crossbred between indicine and taurine breeds, it was expected that the sequence had similarities with both breeds and has been relatively closely related.

\section{CONCLUSION}

Sequence analysis revealed that the alleles were different by having some point mutation at various locations of the fragment, although they showed more than $97 \%$ similarity among each other. The genotypes showed significant association $(\mathrm{p}<0.05)$ with total milk yield, lactation length, daily milk yield and peak yield and non-significant association with somatic cell score during first lactation. 


\section{ACKNOWLEDGEMENT}

The researchers are thankful to Indian Council of Agricultural Research (ICAR), New Delhi, India for providing financial support to carry out this research under ICAR Ad-hoc Scheme.

\section{REFERENCES}

Alharthi, L., K.A. Roebuck and A. Landay, 1998. Induction of HIV-1 replication by type 1-like cytokines, interleukin(IL)-12 and IL-15: Effect on viral transcriptional activation, cellular proliferation and endogenous cytokine production. J. Clin. Immunol., 18: 124-131.

Alluwaimi, A.M., P.V. Rossito, C.M. Leutenegger, T.B. Farver, W.L. Smith and J.S. Cullor, 2003. The cytokines marker in the Staphylococcus aureus mastitis of bovine mammary gland. J. Vet. Med., 50: 105-111.

Bhattacharya, T.K., S. Badola, P. Kumar, A. Shukla and A. Sharma, 2002. PCR-RSP study of IL-2 gene in cattle and buffalo. Proceedings of 7 th World Congress on Genetics Applied to Livestock Production, August 19-23, Montpellier, France.

De Baetselier, P., 1996. Mechanisms Underlying Trypanosome-Induced T-cell Immunosuppression. In: T-Cell Subsets and Cytokines Interplay in Infectious Diseases, Mustafa, A.S., R.J. Al-Attiyah, I. Nath and T.D. Chugh, (Eds.). S Karger, Basel, Switzerland, pp: 124-139.

Diez, B., R. Nicolar, A. Goldeano, R. Cisterna and M.L. Canabate, 1991. Kinetics and regulation of NK activity by $\amalg-2$ and interferon in acute toxoplasmosis. Scand. J. Immunol., 34: 673-677.

Falconar, D.S. and T.F.C. Mackay, 1998. Introduction to Quantitative Genetics. 4th Edn., Addison Wesley Longman Ltd., England.

Harvey, W.R., 1991. Users Guide for LSMLMW, Mixed Model Least Squares and Maximum Likelihood Computer Programme. Ohio State University, Columbus.

Hoffmann, S.C., E.M. Stanley, E.D. Cox, N.D. Craighead and B.S. Mercurio et al., 2001. Association of cytokine polymorphic inheritance and in vitro cytokine production in anti-CD3/CD28-stimulated peripheral blood lymphocytes. Transplantation, 72: 1444-1450.
John, S., D. Turner, R. Donn, P. Sinnott and J. Worthington et al., 1998. Two novel biallelic polymorphisms in the IL-2 gene. Eur. J. Immunogenet., 25: 419-420.

Kinter, A.L., G. Poli, L. Fox, L.E. Hardy and A.S. Fauci, 1995. HIV replication in IL-2-stimulated peripheral blood mononuclear cells is driven in an autocrine/paracrine manner by endogenous cytokines. J. Immunol., 154: 2448-2459.

Luhken, G., S. Hiendleder, E.M. Prinzenberg and G. Erhardt, 2000. A single-strand conformation polymorphism in the ovine interleukin-2 (IL-2) gene. J. Anim. Sci., 78: 2754-2755.

Mansfield, J.M., 1989. Immunology of African Trypanosomiasis. In: Modern Parasite Biology, Wyler, D.G. (Ed.). WH Freeman and Company, New York, pp: $222-246$.

Matesanz, F., M. Fedtaz, L. Levya, C. Delgado, O. Fernandez and A. Alciana, 2004. Effects of the multiple sclerosis associated -330 promoter polymorphism in IL-2 allelic expression. J. Neuroimmunol., 148: 212-217.

Morgan, D.A., F.W. Ruscetti and R. Gallo, 1976. Selective in vitro growth of $\mathrm{T}$ lymphocytes from normal human bone marrows. Science, 193: 1007-1008.

Sambrook, J. and D.W. Russel, 2001. Molecular Cloning-A Laboratory Manual. 3rd Edn., Cold Spring Harbor Laboratory Press, New York, USA.

Taira, S., M. Matsui, K. Hayakawa, T. Yokohama and H. Nariuchi, 1987. Interleukin 2 secretion by B cell lines and splenic B cells stimulated with calcium ionophores and phorbol ester. J. Immunol, 139: 2957-2964.

Taylor, K.A., 1998. Immune responses of cattle to African trypanosomes: Protective or pathogenic? Int. J. Parasitol., 28: 219-240.

Vohra, V., T.K. Bhattacharya, P. Kumar and A. Sharma, 2006. Genetic variants of beta-lactoglobulin gene and its association with milk composition traits in riverine buffalo. J. Dairy Res., 73: 499-503.

Walker, E., T. Leemhuis and W. Roder, 1988. Murine B lymphoma cell lines release functionally active interleukin 2 after stimulation with Straphylococcus aureus. J. Immunol., 140: 859-865.

Warle, M.C., A. Farhan, H.J. Metselaar, W.C.J. Hop and C. Perrey et al., 2003. Are cytokine gene polymorphisms related to in vitro cytokine production profiles? Liver Transpl., 9: 170-181. 